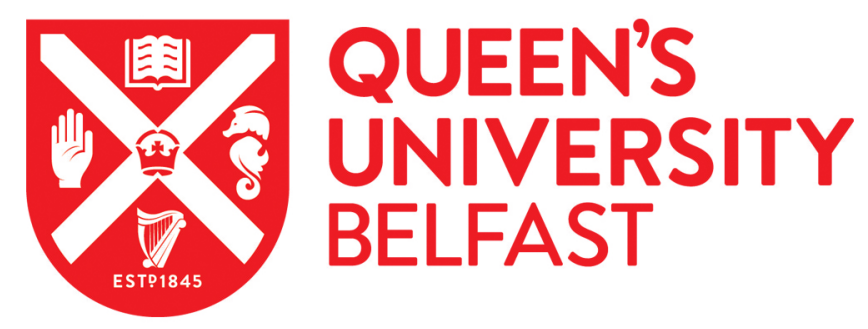

\title{
Eleven phases of Greenland Ice Sheet shelf-edge advance over the past 2.7 million years
}

Knutz, P. C., Newton, A. M. W., Hopper, J. R., Huuse, M., Gregersen, U., Sheldon, E., \& Dybkjær, K. (2019). Eleven phases of Greenland Ice Sheet shelf-edge advance over the past 2.7 million years. Nature geoscience, 12, 361. https://doi.org/10.1038/s41561-019-0340-8

\section{Published in:}

Nature geoscience

\section{Document Version:}

Peer reviewed version

Queen's University Belfast - Research Portal:

Link to publication record in Queen's University Belfast Research Portal

Publisher rights

(C) 2019 The Author(s), under exclusive licence to Springer Nature Limited.

This work is made available online in accordance with the publisher's policies. Please refer to any applicable terms of use of the publisher.

\section{General rights}

Copyright for the publications made accessible via the Queen's University Belfast Research Portal is retained by the author(s) and / or other copyright owners and it is a condition of accessing these publications that users recognise and abide by the legal requirements associated with these rights.

Take down policy

The Research Portal is Queen's institutional repository that provides access to Queen's research output. Every effort has been made to ensure that content in the Research Portal does not infringe any person's rights, or applicable UK laws. If you discover content in the Research Portal that you believe breaches copyright or violates any law, please contact openaccess@qub.ac.uk. 
Eleven phases of Greenland Ice Sheet shelf-edge advance over the past 2.7 million years

2

3 Paul C Knutz ${ }^{1}$, Andrew M W Newton ${ }^{2}$,, John R. Hopper ${ }^{1}$, Mads Huuse ${ }^{2}$, Ulrik Gregersen ${ }^{1}$,

$4 \quad$ Emma Sheldon $^{1}$ and Karen Dybkjær ${ }^{1}$

5

$6{ }^{1}$ Geological Survey of Denmark and Greenland, Øster Voldgade 10, 1350 Copenhagen,

7 Denmark.

$8 \quad{ }^{2}$ School of Earth and Environmental Sciences, The University of Manchester, Williamson

9 Building, Oxford Road, Manchester, M13 9PL, UK.

10 3School of Natural and Built Environment, Queen's University Belfast, BT7 1NN, UK.

\section{ABSTRACT}

13 Reconstruction of former ice sheets is important for testing Earth-system models that can 14 assess interactions between polar ice sheets and global climate, but information retrieved 15 from contemporary glaciated margins is sparse. In particularly, we need to know when ice 16 sheets began to form marine outlets and by what mechanisms they advance and retreat over 17 timescales from decades to millions of years. Here, we use a dense grid of high-quality 2D 18 seismic data to examine the stratigraphy and evolution of glacial outlets, or palaeo-icestreams, 19 draining the northwest Greenland Ice Sheet into Baffin Bay. Seismic horizons are partly age20 constrained by correlation to cores from drill sites. Progradational units separated by on-lap 21 surfaces record eleven major phases of shelf-edge ice advance and subsequent transgression 22 since the first ice sheet expansion $3.3-2.6$ million years ago. The glacial outlet system 23 appears to have developed in four stages, each potentially caused by tectonic and climatic 
changes. We infer that an abrupt change in ice flow conditions occurred during the MidPleistocene transition, about 1 million years ago, when ice movement across the shelf margin changed from widespread to more focused flow (ice streams), forming the present-day glacial troughs.

\section{MAIN TEXT}

Melting of polar ice sheets, driven by global warming, have societally critical consequences for Earth's climate, including abrupt changes in global sea level ${ }^{1,2}$ and oceanic circulation ${ }^{3}$. The potential for climatological tipping points highlights the need for developing comparative studies of past ice-ocean-climate changes to calibrate model simulations of future climate evolution ${ }^{4}$. A recent study using exposure dating suggested that the northern Greenland Ice Sheet (GrIS) was almost completely absent for an extended period of time during the Pleistocene ${ }^{5}$. This implies that Greenland's glaciers were highly sensitive to past warm climate that, unlike the present, were not exacerbated by human-induced $\mathrm{CO}_{2}$ emissions. Other studies, however, favour a continuous, albeit fluctuating, presence of the GrIS over the Pleistocene epoch, suggesting that inland ice domes have persisted since the late Miocene ${ }^{6}$ Thus, more research is needed to refine the contradictory and fragmented records on longterm GrIS dynamics.

The GrIS is drained by ice streams that, over millions of years, have advanced repeatedly to the shelf edge, depositing glacially-eroded sediments onto the continental margins. The geological component of these glacial outlets, known as trough-mouth fans (TMFs), are characterized by km-thick sediment accumulations in front of shelf-crossing troughs that mark the main ice stream drainage route ${ }^{7-9}$. The modern distribution of marine-terminating 
outlet glaciers on glaciated margins is dwarfed by the sizes attained by ice streams during glacial maxima, most recently $22,000-18,000$ years ago ${ }^{10}$. In this study we use an extensive grid of industry seismic reflection data and borehole stratigraphic information to analyse the anatomy and spatial evolution of two palaeo-ice streams that drained into Baffin Bay on the northwest Greenland margin (Fig. 1 and Supplementary Fig. S1) ${ }^{11}$.

\section{Glaciated margin architecture}

Covering an area over 50,000 $\mathrm{km}^{2}$ and with thicknesses exceeding $2 \mathrm{~km}$, the Melville Bugt and Upernavik TMFs form a large sedimentary system resulting from drainage of the northwestern GrIS (Fig. 1). The seabed of the study area is marked by mega-scale glacial lineations (MSGL) formed below fast-flowing ice streams that extended to the shelf break during the last glacial maximum ${ }^{12,13}$. The seismic data reveal a distinct pattern of sequentially organized, prograding depositional units (Fig. 2 and S2). The top of each unit is bounded by planar, laterally continuous reflections that truncate underlying progradational strata with an acoustic response that corresponds to an increase in acoustic velocity. These unconformable relationships are interpreted as the product of repeated advances of the GrIS to the shelf break $^{7}$. They are a distinctive morphological feature that defines the transition from slope clinoforms dipping up to $7^{\circ}-10^{\circ}$ to planar horizons marking abrupt base level rise and transgression (Figs. 2 and 3). The slope segments of the horizons that bound individual units are less distinct than the topset and offlap components, but are often characterized by steep, truncated reflections overlain by packages with hummocky geometries marked by limited lateral continuity (Fig. 3b). These features are interpreted as mass-flow deposits, or glacigenic debrites, that are commonly linked to high sediment fluxes and slope instability at glacial grounding zones ${ }^{14,15}$. Approaching the base-of-slope, the horizons converge into a more 
condensed bottom-set section and occasionally merge with other horizons. Horizon merging is a complicating factor, but by iteratively tracing the horizons throughout the dense 2D data grid, all the main units can be correlated between the different sectors of the glacial fan system, e.g., a full shelf-to-basin transect. By mapping the major glacial unconformities to their shelf break position and continuing along the corresponding basinward dipping reflections, eleven major prograding units have been defined within the TMF system (Fig. 1). The seismic horizons have been converted to metric depths to produce sediment thickness maps and estimate the gross sediment volumes for each of the unit depocentres (Methods, Table S1).

The TMF system consists of a depositional sequence where each of the seismic units and their associated shelf breaks are covered by top-set strata of the succeeding unit (Figs. 2 and 3a; Supplementary Fig. S2). Exceptions to this trend are seen in areas of the present-day troughs where older top-set strata and associated shelf breaks have been truncated by ice stream erosion (Fig. 3b). Apart from this spatially-limited truncation, the depositional configuration of the shelf margin between the Melville Bugt and Upernavik troughs is remarkably wellpreserved. The topset strata are formed by sheeted geometries that expand laterally into asymmetric mounded wedges with internal discontinuous-hummocky or low-angle clinoform reflection patterns (Figs. 3a and S3). These features are interpreted as grounding zone wedges (GZW) formed by rapid accumulation of deforming subglacial tills at the grounding zone of a marine-terminating ice mass ${ }^{16,17}$. Their formation requires sub-glacial accommodation and a high sediment flux. Thus, GZW are commonly associated with deposition below ice shelves or ice that is partly floating ${ }^{18,19}$. These conditions may occur at the shelf edge during the most extensive glacial maxima stages, or at mid-shelf positions during either moderate glacial maxima or intermediate cooling stages during deglaciation. Within the sheeted top-set 
sections of the seismic units, thin reflections are observed that onlap the glacial erosion surfaces and infill intra-shelf depressions between positive topographic features (Fig. 3a). The reflection geometry and acoustic polarity opposite to the seabed is indicative of hemipelagic marine muds or distal glacial-marine sediments ${ }^{20}$. The widespread presence of onlapping strata above the glacial unconformities may be attributed to relatively brief periods when deposition occurred below floating ice or in open marine conditions, and are thus associated with relative sea level rise following glacial retreat from the shelf edge.

\section{Late Cenozoic context and glaciation chronology}

The Neogene - Quaternary succession of the northwest Greenland margin, represented by seismic mega-units (mu) A, B and C, overlies a thick succession of late Mesozoic to earlymiddle Cenozoic strata associated with the rift and post-rift development of Baffin Bay (Fig. $2)^{21}$. The onset of progradation at the base of mu-A occurs above a regional unconformity formed by glacial erosion that truncates the late Neogene sedimentary packages (mu-B and C) from a mid-shelf position and toward the fault-bounded Greenland bedrock. Consequently, late Miocene strata with a predominant mudstone character are exposed in the overdeepened inner-shelf troughs (mu-C, Fig. 2). The youngest strata below the prograding units of the TMF system show asymmetric wavy and mounded geometries attributed to sedimentation by contour-parallel bottom currents (mu-B, Fig. 2) ${ }^{22}$. The abrupt transition from marine current-controlled sedimentation to prograding clinoforms provides a clear physical indication for the onset of shelf-based glaciations in northeast Baffin Bay. Using the dense 2D grid, the seismic stratigraphy of the late Cenozoic package has been extended southwards to the Delta-1 exploration well (Fig. 4). The well biostratigraphy indicates a Pliocene age for mu-B and a likely age range of 3.3-2.6 Ma for the onset of glacial deposition 
120 above a regional late Pliocene horizon (Methods, Fig. S4). North Atlantic deep drilling records

121 point to a major expansion of the GrIS at 2.7-2.8 $\mathrm{Ma}^{6,23-25}$ that corresponds with an increase in

122 the amplitude of 41 kyr orbital cycles in the global $\delta^{18} 0$ record $^{26}$ (Fig. 5a, c-d). By combining

123 the local biostratigraphy with the more detailed North Atlantic chronology, we infer that the

124 northwestern GrIS began to advance beyond the coastline and onto the continental shelf

125 during the latest Pliocene, probably marked by the G6 cooling event at around 2.7 Ma (Fig. 5).

126 The age of the TMF system is further constrained by palaeomagnetic data from cores that

127 were recovered as part of IODP $344 S^{27}$ (Methods, Figs. S2 and S5). The chronological evidence

128 favours an age model that assumes a gross linear relationship between time and TMF

129 accumulation (Fig. S6). The model implies that although glacigenic sediment fluxes across the

130 shelf edge likely varied in response to ice sheet advance/retreat cycles (over orbital and sub-

131 orbital time scales), the long-term sediment delivery, i.e. over 0.5-1.0 Myr, did not change

132 substantially. The approach of using depocentre volumes for inferring TMF evolution is

133 supported by seismic mapping across a large catchment area covering two glacial outlets,

134 which means that spatial flux variations associated with relative shifts in ice stream pathways

135 are evened out. We emphasize, however, that whilst the proposed age model provides a time-

136 averaged picture based on currently available data, future scientific drilling is necessary to

137 improve the chronology of the individual prograding units.

138

139 Trough-mouth fan development

140 The progradational build-out of the northwest Greenland margin, represented by mu-A, can

141 be divided into four development stages (DS) (Fig. 6 and S7). The early development stage

142 (DS-I), comprising units 1-2, is characterized by sediment accumulations that partly cover the

143 present-day troughs and the topographic high to the north ("Northern Bank", Fig. 1). 
144 Increased sediment thickness in the basinward section seen for units 1 and 2 is attributed to 145 large mass-transport deposits observed on seismic profiles as truncated reflections and 146 hummocky surfaces that encase chaotic acoustic signatures (Fig. 2). Potential sources for 147 these deposits are related to erosion and mass-wasting associated with early ice sheet 148 advances over a Neogene succession of unconsolidated marine sediments. DS-II (units 3-4) is 149 characterized by convergence of depocentres towards the area located between the 150 contemporary troughs and the abandonment of sedimentation over the "Northern Bank" area. 151 During DS-III (units 5-7) fan depocentres gradually merge, culminating with a complete 152 amalgamation, reflecting near-uniform rates of margin progradation. From unit 7 to 8 , the 153 sedimentation pattern shifts to a pronounced build-out in front of the two contemporary 154 troughs. This marked lateral change in depocentre shows no transitional phase and thus 155 points to a rapid reorganization in GrIS flow conditions. DS-IV (units 8-11) is further 156 characterized by the accumulation of a drift-channel system seen as elongate thickness 157 anomalies radiating from the depocentres into the basin (Figs. 2 and 6). Similar sedimentary 158 features have been described from the West Antarctic and the southeast Greenland margins 159 and are thought to have been generated by the interaction of oceanic bottom-currents with 160 downslope-moving fine-grained suspension currents ${ }^{28,29}$.

161

162 The early TMF depocentres formed over Cretaceous rift basins (Kivioq and Upernavik basins) 163 that are separated by the Melville Bay Ridge ${ }^{21}$ (MBR) (Figs. 2, 6, S2 and S7). This ridge has a 164 complex post-rift tectonic history influenced by strike-slip and compressional motion during 165 the late Palaeogene and later. The resulting vertical adjustments triggered regional slope 166 instability and vertical incision of the late Miocene succession ${ }^{21,22}$. The MBR strikes SE-SW and 167 deepens southwards by more than $1200 \mathrm{~m}$ over a distance of about $40 \mathrm{~km}$. At its shallowest 
168

169

170

171

172

173

174

175

176

177

178

179

180

181

182

183

184

185

186

187

188

189

190

point, aggradational strata of unit 3 truncate the ridge, while to the south it is deeply buried by late Cenozoic sediment packages. The depocentre distribution and internal progradation patterns of units 1-3 imply that during the early phase of shelf glaciation, ice drained across the present topographic high of the "Northern Bank", which is underpinned by the shallow ridge segment (Fig. 6). It is notable that the convergence and subsequent amalgamation of the glacigenic depocentres (DS II-III) occurs across an area underlain by the distal MBR (Fig. S7). This suggests that the progressive shifts in Early Pleistocene ice stream routes toward the central parts of the TMF system were controlled by relative movements of the ridge. As progradation gradually moved into deeper water, accommodation may have been accentuated by local tectonic adjustments, including flexure and associated fault-reactivation of the underlying crust due to sediment loading. To summarize, we infer that the deposition and the top-set preservation of the TMF system is the result of high glacial sediment fluxes from the northwest GrIS in concert with favourable geological circumstances that include long-term basin subsidence of deep-seated structural elements.

\section{Implications for Greenland Ice Sheet dynamics}

The seismic-stratigraphic evidence shows that during the Early Pleistocene, the northwest GrIS was drained by prominent but geographically transient ice streams terminating in Baffin Bay (DS I-II, Fig. 6). The palaeo-ice streams were likely associated with temperate or polythermal basal conditions that, combined with the presence of deformable substrata, determined their ability to form cross-shelf troughs linked with fan depocentres ${ }^{30-32}$. The glacial outlets may have been connected to ice shelves, that would extend the marine ablation zone to a wider area in front of the grounding line ${ }^{33}$.

191 
192 The merging of fan depocentres, culminating in a single, elongate accumulation zone (DS III)

193 signals a gradual change in the mode of sub-glacial transport toward the end of the Early

194 Pleistocene ( 1.5-1.0 Ma, Fig. 5). Similar elongate margin progradation of the Early

195 Pleistocene interval has been identified on other glaciated margins ${ }^{34}$, but its significance for

196 palaeo-ice sheet dynamics remains elusive. The ice flow conditions associated with a linear

197 ablation zone extending along the shelf margin for over $200 \mathrm{~km}$ is incompatible with focussed

198 ice stream glaciation maintained by basal sliding and high meltwater production. Ice streams

199 with similar widths have not been observed in the geological or contemporary record ${ }^{35}$ and it

200 seems unlikely that ice sheet volume in northwest Greenland was sufficiently large to sustain

201 a $200 \mathrm{~km}$-wide ice stream. More likely, the even dispersal of sediments reflects a wide glacial

202 front advancing with laterally uniform flow velocities over a deformable bed ${ }^{30,36}$. A possibility

203 is that DS III reflects a long-term equilibrium between warm-based ice and its sedimentary

204 based grounding zones, which was attained after the shelf margin became smoothed by

205 earlier glacial erosion, i.e. limiting the potential for topographic focusing (streaming) of ice

206 flow. This development toward a continuous ablation front could also be influenced by ice

207 sheet dynamics responding to the 41 kyr climate cycles (Fig. 5a).

208

209 The shift from even progradation along the entire shelf front (unit 7) to the build-out of 210 crescent-shaped fans (unit 8) (Fig. 6), points to a radical change in glacial flow conditions 211 resulting in focused sediment delivery to the shelf margin. This reorganisation likely occurred 212 at the start of the Mid-Pleistocene transition (MPT: 1.1-0.7 Ma) that demarcates the onset of $213100 \mathrm{kyr}$ orbital cycles and a steady increase in the magnitude of sea-level low-stand events 214 from $\sim 70$ to $130 \mathrm{~m}^{26,37}$ (Fig. 5a). A broad correlation between Unit 8 and the MPT is 215 consistent with an erosional deepening of the shelf break grounding line through units 8-9 
216 which may reflect the extreme sea-level lows of MIS (Marine Isotope Stage) 12 and 16 (Figs. 1,

$2173 \mathrm{~b}$ and 5a). Furthermore, Unit 8 corresponds to the onset of sedimentary drift accumulation

218 juxtaposed to slope channels, suggesting that the production and downslope transport of fine-

219 grained sediments increased during the MPT. The changes in deposition during DS IV reflects

220 the wide configuration of the Melville Bugt outlet in contrast to the structurally confined

221 Upernavik Trough, flanked to the south by early Cenozoic volcanic terrain (Fig. S7).

222 Explanations for the MPT include (1) ice sheet dynamics controlled by bedrock conditions and

223 the extent of ice-ocean contact zones ${ }^{38}$, (2) feedback between ice albedo and $\mathrm{CO}_{2}$ reservoir

224 exchanges $^{39}$, (3) tectonic base-level adjustments ${ }^{40}$, and (4) antiphase relationships in

225 interhemispheric ice volume changes ${ }^{41}$. Clark and Pollard (1998) ${ }^{38}$ proposed that removal of

226 deformable sediments (regolith) below northern hemisphere ice sheets increased basal

227 friction, thus allowing more ice to remain above the equilibrium line and eventually causing a

228 transition to thicker ice sheets phase-locked to weak eccentricity forcing. The change from a

229 spatially homogenous advance to focused, deeply grounded, and likely fast-flowing, outlet

230 glaciers, as expressed by units 7-8 (Fig. 6), may be a response to changing basal dynamics

231 and/or volumetric expansion of the GrIS associated with the onset of $100 \mathrm{kyr}$ glaciations $6,25,42$.

232 Nevertheless, the question of why the glaciated margin evolved from focused ice streams

233 during the early phase of shelf glaciation to even margin progradation leading up to the MPT,

234 and then followed by a return to focused ice-stream behavior during the Middle-Late

235 Pleistocene remains unanswered. The complexity of this evolution suggests that the GrIS is

236 influenced by factors other than global climate and insolation-driven dynamics.

238 Since the first shelf edge expansion of the northwestern GrIS, likely about $2.7 \mathrm{Ma}$, eleven

239 prograding units are identified, each representing multiple cycles of glacial advances across 
the shelf margin. Comparison of our data with regional palaeoclimate records may provide further insights to the instrumental mechanisms for the observed changes in glacial outlet configuration (Fig. 5). Here we note that for the Early Pleistocene interval, constrained by stratigraphic ties to boreholes, shifts in glacial deposition overlaps with the estimated ages of 244 Kap København Fm A-B and Store Koldewey Fm - deposits indicating boreal tundra 245 conditions in northern parts of Greenland ${ }^{43,44}$. This correlation points to a potential connection between shifts in ice flow pathways and prominent interglacials ${ }^{45,46}$ (Fig. 5b) but further verification is precluded by the younger and chronologically unconstrained part of the record. Nevertheless, the parallel reflections onlapping the erosional unconformities in the palaeo-shelf areas (Fig. 3) suggests that major glacial advances were intermittently replaced 250 by floating ice or open marine conditions.

The depositional record of the Melville Bugt - Upernavik TMF system demonstrates repeated 253 reorganization of ice flow patterns that apparently involved relative sea-level rises broadly 254 occurring every 200-400 kyr. Most conspicuous is the fundamental change in shelf margin 255 glaciation style toward the end of the Early Pleistocene, which may suggest a linkage between 256 GrIS dynamics and the increase in glacial intensities through the MPT. These results document 257 large-scale temporal variations in past GrIS flow dynamics that can help to constrain 258 numerical modelling aimed at understanding Pleistocene ice sheet behavior.

\section{REFERENCES (MAIN TEXT)}

2611 Overpeck, J. T., Otto-Bliesner, B. L., Miller, G. H., Muhs, D. R., Alley, R. B. \& Kiehl, J. T. 262 Paleoclimatic evidence for future ice-sheet instability and rapid sea-level rise. Science 263 311, 1747-1750 (2006). 
2642 Rignot, E., Velicogna, I., van den Broeke, M. R., Monaghan, A. \& Lenaerts, J. Acceleration

265 of the contribution of the Greenland and Antarctic ice sheets to sea level rise.

$266 \quad$ Geophysical Research Letters 38 (2011).

2673 Rahmstorf, S., Box, J. E., Feulner, G., Mann, M. E., Robinson, A., Rutherford, S. \&

268 Schaffernicht, E. J. Exceptional twentieth-century slowdown in Atlantic Ocean

269 overturning circulation. Nat Clim Change 5, 475-480, doi:10.1038/nclimate2554

$270 \quad((2015))$.

2714 Koenig, S. J. et al. Ice sheet model dependency of the simulated Greenland Ice Sheet in

272 the mid-Pliocene. Climate of the Past 11, 369-381 (2015).

2735 Schaefer, J. M. et al. Greenland was nearly ice-free for extended periods during the $274 \quad$ Pleistocene. Nature 540, 252-255 (2016).

2756 Bierman, P. R., Shakun, J. D., Corbett, L. B., Zimmerman, S. R. \& Rood, D. H. A persistent 276 and dynamic East Greenland Ice Sheet over the past 7.5 million years. Nature 540, 256$277260(2016)$.

2787 Larter, R. D. \& Barker, P. F. Seismic Stratigraphy of the Antarctic Peninsula Pacific 279 Margin - a Record of Pliocene-Pleistocene Ice Volume and Paleoclimate. Geology 17, $280 \quad 731-734(1989)$.

2818 Cooper, A. K., Barret, P. J., Hinz, K., Traube, V., Leitchenkov, G. \& Stagg, H. M. J. Cenozoic 282 prograding sequences of the Antarctic continental margin: a record of glacio-eustatic 283 and tectonic events. Marine Geology 102, 175-213 (1991).

2849 Vorren, T. O. \& Laberg, J. S. Trough mouth fans - Palaeoclimate and ice-sheet monitors. 285 Quaternary Science Reviews 16, 865-881 (1997).

28610 Denton, G. H. \& Hughes, T. The last great ice sheets. (Wiley, 1981). 
11 Jakobsson, M. et al. The International Bathymetric Chart of the Arctic Ocean (IBCAO) Version 3.0. Geophysical Research Letters 39 (2012).

12 Slabon, P., Dorschel, B., Jokat, W., Myklebust, R., Hebbeln, D. \& Gebhardt, C. Greenland ice sheet retreat history in the northeast Baffin Bay based on high-resolution bathymetry. Quaternary Science Reviews 154, 182-198 (2016).

292

Newton, A. M. W., Knutz, P. C., Huuse, M., Gannon, P., Brocklehurst, S. H., Clausen, O. R. \& Gong, Y. Ice stream reorganization and glacial retreat on the northwest Greenland shelf. Geophys. Res. Lett. 44, doi:10.1002/2017GL073690 (2017).

Laberg, J. S. \& Vorren, T. O. Late Weichselian submarine debris flow deposits on the Bear Island Trough Mouth Fan. Marine Geology 127, 45-72 (1995).

Ó Cofaigh, C., Dowdeswell, J. A., Evans, J., Kenyon, N. H., Taylor, J., Mienert, A. \& Wilken, channels of the Greenland Basin. Marine Geology 207, 39-54 (2004).

30016 Batchelor, C. L. \& Dowdeswell, J. A. Ice-sheet grounding-zone wedges (GZWs) on highlatitude continental margins. Marine Geology 363, 65-92 (2015).

Dowdeswell, J. A. \& Fugelli, E. M. G. The seismic architecture and geometry of grounding-zone wedges formed at the marine margins of past ice sheets. Geol Soc Am Bull 124, 1750-1761, doi:10.1130/B30628.1 (2012). sedimentation on ice-sheet grounding-line stability. Science 315, 1838-1841 (2007).

Dowdeswell, J. A., Ottesen, D., Rise, L. \& Craig, J. Identification and preservation of 308 landforms diagnostic of past ice-sheet activity on continental shelves from three309 dimensional seismic evidence. Geology 35, 359-362, doi:Doi 10.1130/G23200a.1 (2007). 
$31120 \quad$ Belknap, D. F. \& Shipp, R. C. in Glacial marine sedimentation; Paleoclimatic significance

312 GSA Special Papers (eds J.B. Anderson \& G.M. Ashley) (Geological Society of America,

313 1991).

31421 Gregersen, U., Hopper, J. R. \& Knutz, P. C. Basin seismic stratigraphy and aspects of 315 prospectivity in the NE Baffin Bay, Northwest Greenland. Mar Petrol Geol 46, 1-18 316 (2013).

31722 Knutz, P. C., Hopper, J. R., Gregersen, U., Nielsen, T. \& Japsen, P. A contourite drift 318 system on the Baffin Bay-West Greenland margin linking Pliocene Arctic warming to 319 poleward ocean circulation. Geology 43, 907-910, doi:10.1130/G36927.1 (2015).

32023 Jansen, E., Fronval, T., Rack, F. \& Channell, J. E. T. Pliocene-Pleistocene ice rafting 321 history and cyclicity in the Nordic Seas during the last 3.5 Myr. Paleoceanography 15, $322 \quad 709-721(2000)$.

32324 Wolf, T. C. W. \& Thiede, J. History of terrigenous sedimentation during the past 10 m.y. 324 in the North Atlantic (ODP Legs 104 and 105 and DSDP Leg 81). Marine Geology 101, 325 83-102 (1991).

32625 Hodell, D. A. \& Channell, J. E. T. Mode transitions in Northern Hemisphere glaciation: 327 co-evolution of millennial and orbital variability in Quaternary climate. Climate of the $328 \quad$ Past 12, 1805-1828 (2016).

32926 Lisiecki, L. E. \& Raymo, M. E. A Pliocene-Pleistocene stack of 57 globally distributed 330 benthic delta 0-18 records. Paleoceanography 20, 1-17, doi:10.1029/2004pa001071 $331 \quad$ (2005).

33227 Acton, G. \& members, e. Expedition 344S - Proceedings of the Baffin Bay Scientific 333 Coring Program. (2012). 
33428 Clausen, L. The Southeast Greenland glaciated margin: 3D stratal architecture of shelf

335 and deep sea. Geological Society, London, Special Publications 129, 173-203,

336 doi:10.1144/GSL.SP.1998.129.01.12 (1998).

33729 Rebesco, M., Larter, R. D., Camerlenghi, A. \& Barker, P. F. Giant sediment drifts on the 338 continental rise west of the Antarctic Peninsula. Geo-Mar Lett 16, 65-75 (1996).

$33930 \quad$ Alley, R. B., Cuffey, K. M., Evenson, E. B., Strasser, J. C., Lawson, D. E. \& Larson, G. J. How 340 glaciers entrain and transport basal sediment: Physical constraints. Quaternary Science $341 \quad$ Reviews 16, 1017-1038 (1997).

34231 Stokes, C. R. \& Clark, C. D. Palaeo-ice streams. Quaternary Science Reviews 20, 1437-

343 1457, doi:Doi 10.1016/S0277-3791(01)00003-8 (2001).

34432 Boulton, G. S., Dongelmans, P., Punkari, M. \& Broadgate, M. Palaeoglaciology of an ice 345 sheet through a glacial cycle. Quaternary Science Reviews 20, 591-625 (2001).

34633 Shabtaie, S. \& Bentley, C. R. West Antarctic ice streams draining into the Ross Ice Shelf

347 - configuration and mass balance. Journal of Geophysical Research-Solid Earth and

$348 \quad$ Planets 92, 1311-1336 (1987).

34934 Ottesen, D., Rise, L., Andersen, E. S., Bugge, T. \& Eidvin, T. Geological evolution of the $350 \quad$ Norwegian continental shelf between $61^{\circ} \mathrm{N}$ and $68^{\circ} \mathrm{N}$ during the last 3 million years. $351 \quad$ Norw J Geol 89, 251-265 (2009).

35235 Margold, M., Stokes, C. R. \& Clark, C. D. Ice streams in the Laurentide Ice Sheet: 353 Identification, characteristics and comparison to modern ice sheets. Earth-Sci Rev 143, 354 117-146, doi:10.1016/j.earscirev.2015.01.011 (2015).

35536 Mcintyre, N. F. The Dynamics of Ice-Sheet Outlets. J Glaciol 31, 99-107 (1985). 
35637 Miller, K. G., Mountain, G. S., Wright, J. D. \& Browning, J. V. A 180-Million-Year Record of

357 Sea Level and Ice Volume Variations from Continental Margin and Deep-Sea Isotopic

358 Records. Oceanography 24, 40-53 (2011).

35938 Clark, P. U. \& Pollard, D. Origin of the middle Pleistocene transition by ice sheet erosion $360 \quad$ of regolith. Paleoceanography 13, 1-9 (1998).

36139 Ruddiman, W. F. Orbital changes and climate. Quaternary Science Reviews 25, 3092-

$362 \quad 3112(2006)$.

36340 Crowley, T. J. Cycles, cycles everywhere. Science 295, 1473-1474 (2002).

36441 Raymo, M. E., Lisiecki, L. E. \& Nisancioglu, K. H. Plio-pleistocene ice volume, Antarctic

365 climate, and the global delta(18)0 record. Science 313, 492-495, doi:DOI

$366 \quad 10.1126 /$ science.1123296 (2006).

36742 Chalk, T. B. et al. Causes of ice age intensification across the Mid-Pleistocene Transition. $368 \quad$ P Natl Acad Sci USA 114, 13114-13119 (2017).

36943 Funder, S., Bennike, O., Bocher, J., Israelson, C., Petersen, K. S. \& Simonarson, L. A. Late 370 Pliocene Greenland - The Kap Kobenhavn Formation in North Greenland. Bulletin of the 371 Geological Society of Denmark 48, 117-134 (2001).

37244 Bennike, O., Knudsen, K. L., Abrahamsen, N., Bocher, J., Cremer, H. \& Wagner, B. Early 373 Pleistocene sediments on Store Koldewey, northeast Greenland. Boreas 39, 603-619, 374 doi:DOI 10.1111/j.1502-3885.2010.00147.x (2010).

37545 Melles, M. et al. 2.8 Million Years of Arctic Climate Change from Lake El'gygytgyn, NE $376 \quad$ Russia. Science 337, 315-320 (2012).

$37746 \quad$ Reyes, A. V. et al. South Greenland ice-sheet collapse during Marine Isotope Stage 11. $378 \quad$ Nature 510, 525-528 (2014). 
Materials \& Correspondence.

381 Any request should be addressed to the lead author (pkn@geus.dk)

382

383

384

385

386

387

388

389

390

391

392

393

394

395

396

397

398

399

400

\section{Acknowledgements}

TGS Geophysical company is acknowledged for use of seismic data. AMWN was supported by the Natural Environmental Research Council (NERC grant reference number NE/K500859/1) and Cairn Energy, whom funded his PhD.

\section{Author contributions.}

P.C.K. is the initiator and lead author of the study. As part of his PhD project, A.M.W.N. provided complimentary results and contributed to the discussion. J.R.H. provided data for the depth conversion and contributed to the interpretation and discussion. M.H. contributed to the interpretation and discussion. U.G. provided input to the seismic interpretation. E.S. and K.D. contributed with a biostratigraphic analyses of industry well data.

Competing financial interests.

There are no competing financial interests associated with this submission.

\section{FIGURE CAPTIONS}

Figure 1. Map of study area with displayed seismic lines and palaeo-shelf break positions of glacigenic prograding units. Seabed topography, illustrated by grey-scale dipmap, is based on first reflection from 2D and 3D seismic data. Bathymetry in the regional overview (inset, top right) (inset), shown at $300 \mathrm{~m}$ contour intervals, is from IBCAOv3 ${ }^{11}$. Key drill sites are marked in red. See Fig. S1 for the full seismic data grid. Present shelf-break and palaeo-shelf breaks 
401 (units 1-10, late Pliocene) are marked by coloured curves (mbss: meters below sea surface). MSGL = Mega-scale glacial lineations. IFT = Inter-fan trough.

403

Figure 2. Seismic profile NE-SW across the Melville Bugt (line position shown in Fig. 1) with 405 key stratigraphic horizons shown in colour. The late Cenozoic succession is partitioned by 406 seismic mega-units (m.u.) A-D. Numbers 1-11 denote glacigenic prograding units within mega-unit A. LPU = Late Pliocene Unconformity, MBR = Melville Bay Ridge, MTD = masstransport deposits, DCS = drift-channel system. Vertical scale is displayed in two-way travel time (twtt) seconds. Box indicate zoom-in shown in Fig. 3a.

410

Figure 3. Seismic cross-sections representing the aggradational interfan area (a) and the Melville Bugt trough area (b). Line positions are shown in Fig. 1. Denotation of stratigraphic horizons and units similar to Fig. 2. White circles indicate intersection with shelf breaks shown in Fig. 1. Triangles point to lenticular strata geometries inferred as grounding zone wedges. Reflections onlapping glacial unconformities are demarcated by green arrows (a, inset). Individual clinoform wedges, displaying discontinuous-hummocky reflection patterns, are interpreted as glacigenic debris flows (b, examples marked by black arrows).

Figure 4. Seismic profile SE-NW across the drill site of Delta-1 located south of the main study area (Fig. 1 inset). The displayed well logs are resistivity (blue-purple) and gamma-ray 
424 Figure 5. Correlation of the northwest GrIS prograding system (units 1-11, development

425 stages I-IV) with regional and global climate proxies from 3.4 Ma to present. (a) Global sea-

426 level curve ${ }^{37}$ constructed from the LR4 benthic $\delta^{18} 0$ stack $^{26}$ with thin, broken lines

427 demarcating trends in sea-level low stands. (b) Si/Ti record from Lake El' Gygytgyn, northeast

428 Russia, with high values indicating warmer Arctic climates ${ }^{45}$. (c) Flux of coarse fraction $(>63$

$429 \mu \mathrm{m}$ ) from ODP 646, eastern Labrador Sea ${ }^{24}$ with single-point outliers omitted to obtain

430 background signal. (d) Natural Gamma-Ray (NGR) variation from site U1308 reflecting flux of

431 glacial weathering products to the central North Atlantic ice-rafting belt ${ }^{25}$. Unit 3, cored at

432 sites U0100/110 (red bar) is correlated to the Olduvai (0) sub-Chron (age model explained in

433 Methods and Supplementary Figures S4-S6). SKF = Store Koldewey Fm. KKF = Kap København

434 Fm. (sections A and B).

435

436 Figure 6. Thickness maps for each of the prograding units. Thick white lines demarcate the 437 shelf break position of the top horizon (as in Fig. 1). Red arrows show inferred routes of 438 streaming ice. MTD = mass-transport deposits, GZW = grounding zone wedge, DCS = Drift-

439 Channel System. BFF $=$ Basin-floor fan. Thicknesses $<30 \mathrm{~m}$ (white areas) are considered to be 440 below the seismic resolution. Position of coring sites U0100/110 shown in the Unit 3 panel.

METHODS

\section{Data and seismic mapping}

444 The seismic mapping is based on data acquired by TGS from 2007-2010 in the Baffin Bay 445 along the West Greenland margin (Fig. S1). The sedimentary succession was mapped 446 previously and subdivided into genetically related mega-units ${ }^{21,22}$ based on seismic 447 stratigraphic principles ${ }^{47}$. The focus in this study is the Melville Bugt - Upernavik Trough- 
Mouth Fan (TMF) system forming part of mega-unit A (Fig. 2). The TMF package is comprised of prograding sediment wedges separated by glacial unconformities and corresponding basinward reflections. The glacial unconformities over the shelf areas are interpreted as the product of grounded ice that formed during periods of glacial expansion across the palaeoshelves and terminating at the shelf-break. In parts where the top-set strata of the TMF are well-preserved, thin, horizontal strata are seen to onlap the glacial unconformities, suggesting phases of marine transgressions that formed after the retreat of grounded ice (Fig. 3a). The base of the TMF system is defined by an unconformity of likely late Pliocene age that caps a Neogene marine sequence (see biostratigraphy below). Seismic interpretation was carried out using Petrel 2016 software. The seismic horizons were gridded using a cell size of $200 \times 200$ attribute extracted from each of the horizons.

\section{Depth conversion and sediment volume calculation}

Gridded surfaces representing the top of units 1-11 (top unit 11 is the seabed) were depth converted in Petrel. Because there are no seismic refraction data available in the area, we used plausible velocities based on similar glaciated margins ${ }^{48,49}$ and nearby well data. A simple layered model consisting of a water layer over a consolidated sediment layer was assumed, since glaciated margins typically have at most only a thin veneer of unconsolidated sediments. The water velocity assumed is $1460 \mathrm{~m} \mathrm{~s}^{-1}$. Off Svalbard, the top velocity of the consolidated glacial sediment layer varies from $2100-2300 \mathrm{~m} \mathrm{~s}^{-1}$ and velocity gradients range from $0.3-0.7 \mathrm{~m} \mathrm{~s}^{-1} \mathrm{~m}^{-1}$. These velocities and gradients are consistent with velocities observed 
471 velocity of $2100 \mathrm{~m} \mathrm{~s}^{-1}$ and a gradient of $0.5 \mathrm{~m} \mathrm{~s}^{-1} \mathrm{~m}^{-1}$ in the consolidated sediment layer were 472 assumed.

473

474 Isochores were then computed based on the depth converted gridded horizons. Gross 475 sediment volumes were calculated for the shelf margin depocentres of each seismic unit by 476 constructing polygons tracing the $300 \mathrm{~m}$ thickness contour that most consistently defines the 477 depocentre geometries (Table S1). Confining the unit volumes to the shelf margin depocentres 478 ensured that gross volumes were comparable and strictly related to glacial sediment 479 transport through the Melville Bugt - Upernavik TMF system, while reducing the influence 480 from other sediment sources, e.g. alongslope transport from nearby glacial outlets. The 481 sediment volumes contained in the depocentres represent gross averages of glacially derived 482 sediments produced primarily by subglacial and englacial transport. In addition to material 483 eroded from the Greenland basement, this includes an unknown component of sediments 484 reworked from the shelf region, e.g. exposed Neogene strata, older tills and interglacial 485 deposits. However, regardless of the ratio between far-travelled and locally eroded material, 486 the marginal depocentres represent the final sink of sediments derived by drainage of a large 487 sector of the north-west Greenland ice sheet, e.g., about $1 / 7$ of its surface area based on 488 current ice flow data 50.

\section{Chronology of trough-mouth fan evolution}

491 The Delta-1 well located on a mid-shelf position south of the main study area drilled through a 492 thick late Cenozoic section (Figs. 1 and 3 ). The biostratigraphic information ${ }^{51}$ from late 493 Neogene marine deposits, corresponding to mega-units B and C, below the glacigenic package 494 was used to obtain a chronology for the likely onset of shelf-based glaciation (Fig. S4). Age 
495

496

497

498

499

500

501

502

503

504

505

506

507

508

509

510

511

512

513

514

515

516

517

518

estimates were given based on the first and last occurrences of dinocyst species as well as calcareous benthic and agglutinated foraminifera. Interpretation of the dinocyst assemblages were based on earlier studies from the Labrador Sea/Baffin Bay ${ }^{52-54}$, north-eastern Atlantic ${ }^{55}$, Iceland ${ }^{56}$ and the North Sea ${ }^{57}$. The age range of foraminiferal bio-events was based on previous results from North Greenland 58 , East Greenland ${ }^{59}$, the Norwegian $\operatorname{margin}^{60}$, and the North Sea61. A late Pliocene - Early Pleistocene age for the B1 horizon is supported by an increase in abundance and diversity of calcareous benthic foraminifera ${ }^{59}$, including Elphidium excavatum group, Bucella frigida, Elphidium albiumbilicatum and Elphidium bartletti, observed between $940-810 \mathrm{~m}$ in the Delta-1 well (Fig. S4). The well-tie provides a more robust age range for the onset of shelf-based glaciation than was previously inferred based on longdistance correlation to ODP Site 645 in the southwest Baffin Bay²2.

A late Pliocene onset of shelf margin glaciation in Melville Bay is commensurate with previous results from central West Greenland based on seismic-well correlation ${ }^{62}$. In comparison, glaciation began to influence the central East Greenland margin already in the late Miocene ${ }^{63}$ but with major progradation of the Scoresby Sund TMF taking place during the Pleistocene ${ }^{64}$. For the southwest Greenland margin, an onset of glaciation 4.4-4.6 Ma was suggested 65 , i.e. 1.1-2.0 Ma earlier than initial glacial advance inferred for central and northern parts of West Greenland. This deviation may partly relate to differences in the definition of the glaciation signatures tied to well biostratigraphy. In the present study and that of Hofmann et al. $(2016)^{62}$, the onset of glaciation is inferred directly from the age of marine sediments encountered below glacigenic deposits on the shelf margin. The approach used by Nielsen and Kuijpers (2013) associates the oldest of a series of large mass-transport deposits (MTD), seen at the base of the glacigenic wedge, with the first shelf-edge ice advance in the Davis Strait 
region. Given that climate modeling results suggest that Pliocene ice was limited to highelevation areas $^{4}$ two plausible scenarios may be considered: either, the oldest MTD was triggered by a brief glacial advance during an early Pliocene cooling stage, or, alternatively, the deposit was formed by slope instability processes unrelated to glacial loading.

A further age constraint on the trough-mouth fan evolution is provided by palaeo-magnetic data obtained from shallow cores recovered at sites U0100 and U0110 in northeast Baffin Bay ${ }^{27,66}$. These sites were drilled over the "Northern Bank" at a position where Unit 3 is clearly defined in the seismic data, above a major unconformity eroding the Melville Bay Ridge (Fig. S2). We therefore consider the age of the recovered sediments to represent the topmost part of Unit 3. The results show a normal polarity for the cored interval, except for an apparent geomagnetic reversal recorded in the upper part of the drilled succession (Fig. S5). The consistency of the inclination for the normal polarity interval, measured on discrete samples from two neighboring sites, covering a stratigraphic section of $>50 \mathrm{~m}$, negates the possibility that this could be a geomagnetic excursion within a reversed polarity chron or subchron. Potential age correlations related to the normal palaeomagnetic phase of Unit 3 includes the Brunhes Chron (0-0.8 Ma), Jamarillo sub-Chron (1.0-1.1 Ma) or the Olduvai subChron (1.8-2.0 Ma) ${ }^{67}$. The first two options imply that gross depositional fluxes were very low during the first three glacial advance mega-cycles and then increased to at least threefold values from Unit 4 and onwards (Fig. S6). If the top of Unit 3 corresponds to the Jamarillo subChron then the average shelf-edge sedimentation rates during deposition of units 8-11 would be 1.5-2.0 m kyr-1 compared to $0.5-0.7 \mathrm{~m} \mathrm{kyr}^{-1}$ for units 1-3. To explain such an abrupt change in long-term sediment fluxes, requires that the northern GrIS was dynamically resilient with a low erosional capability throughout the late Pliocene and most of the Early Pleistocene. 
543 However, this scenario is not supported by evidence from deep-sea records indicating that 544 supply of IRD during the Early Pleistocene was similar to that observed for the Late 545 Pleistocene ${ }^{23,64,68}$. Moreover, changes in cosmogenic isotope composition $\left({ }^{26} \mathrm{Al},{ }^{10} \mathrm{Be}\right)$ points to 546 intensified glacial erosion in East Greenland during the Early to Middle Pleistocene ${ }^{6}$. 547 Therefore, the normal palaeo-magnetic phase of Unit 3 is most likely matched with the 548 Olduvai sub-Chron, consistent with a linear relationship between cumulative age and 549 sediment volumes since the onset of progradation (Fig. S6). The preferred age model that 550 befits both previous observations from proxy-based studies (Figs. 5c-d) and the palaeo551 magnetic signature of Unit 3 implies that gross sediment fluxes across the shelf margin were 552 on average relatively constant over the long time scale considered here, i.e. several millions of 553 years. We stress, however, that the approach of calculating large volumetric entities involves 554 an averaging process which must be assumed to conceal sediment flux changes over shorter 555 time scales such as orbital periodicities associated with global changes in ice volume. Thus, it 556 is implicit that short hiatuses and spikes in sedimentation rates do not have a significant 557 impact on the longer term averages.

558

\section{Age model uncertainty}

560 Provided that the seismic unconformities have been interpreted consistently throughout the 561 study area, the absolute sediment volumes determined for each of the depositional units are 562 dependent on the (1) time-to-depth conversion procedure and (2) the thickness threshold for 563 defining the shelf margin depocentres as described above. However, varying the parameters 564 for these procedures affects the units systematically (e.g. in a similar direction) and thus will 565 not significantly influence the relative distribution of the sediment volumes over the time 566 span of TMF deposition. The uncertainty associated with the age model is therefore primarily 
related to the scarcity of age control within the prograding succession, especially between seismic units 3 to 11 . With only one internal age control point, quantification of error margins for the unit ages, e.g. using statistical methods such as Monte Carlo simulation, becomes arbitrary and reliant on a pre-defined confidence level. The lack of well-defined unit ages is illustrated by white gaps between the depositional units shown in Fig. 5. The uncertainty may be in the range of several orbital cycles, e.g. $\pm 50-100 \mathrm{ka}$, corresponding to $\pm 2-4 \%$ variation in gross sedimentary fluxes, although this needs testing by further sampling and dating of the TMF units.

\section{METHODS REFERENCES}

47 Mitchum, R. M., Vail, P. R. \& Sangree, J. B. Seismic stratigraphy and global changes of sealevel, Part 6: Stratigraphic interpretation of seismic reflection in depositional sequences Application of Seismic Reflection Configuration to Stratigrapic Interpretation Memoir 26, 117-133 (1977).

48 Geissler, W. H. \& Jokat, W. A geophysical study of the northern Svalbard continental margin. Geophys J Int 158, 50-66 (2004).

49 Geissler, W. H., Jokat, W. \& Brekke, H. The Yermak Plateau in the Arctic Ocean in the light of reflection seismic data-implication for its tectonic and sedimentary evolution. Geophys J Int 187, 1334-1362 (2011).

50 Joughin, I., Smith, B. E., Howat, I. M., Scambos, T. \& Moon, T. Greenland flow variability from ice-sheet-wide velocity mapping. J Glaciol 56, 415-430 (2010).

51 Cairn-Ichron. A biostratigraphic evaluation of Delta-1 and Gamma-1, West Disko licence area, West Greenland. (2012). 
59052 de Vernal, A. \& Mudie, P. J. in Proc. ODP, Sci. Results Vol. 105 (eds S.P. Srivastava, M.A. 591 Arthur, \& B. Clement, et al.) 401-422 (1989).

59253 Piasecki, S. Neogene dinoflagellate cysts from Davis Strait, offshore West Greenland. $593 \quad$ Mar Petrol Geol 20, 1075-1088 (2003).

$59454 \quad$ Fensome, R. A., Nøhr-Hansen, H. \& Williams, G. L. Cretaceous and Cenozoic

595 dinoflagellate cysts and other palynomorphs from the western and eastern margins of 596 the Labrador-Baffin Seaway. Geol Surv Den Greenl 36, 143 (2016).

59755 De Schepper, S. \& Head, M. J. Pliocene and Pleistocene Dinoflagellate Cyst and Acritarch 598 Zonation of Dsdp Hole 610a, Eastern North Atlantic. Palynology 33, 179-218 (2009).

59956 Verhoeven, K., Louwye, S., Eiriksson, J. \& De Schepper, S. A new age model for the 600 Pliocene-Pleistocene Tjornes section on Iceland: Its implication for the timing of North 601 Atlantic-Pacific palaeoceanographic pathways. Palaeogeography Palaeoclimatology $602 \quad$ Palaeoecology 309, 33-52 (2011).

60357 Dybkjær, K. \& Piasecki, S. A new Neogene biostratigraphy for Denmark. Geol Surv Den $604 \quad$ Greenl 15, 29-32 (2008).

60558 Feyling-Hanssen, R. Foraminiferal stratigraphy in the Plio-Pleistocene Kap København 606 Formation, North Greenland. Meddelelser om Grønland, Geoscience 24, 3-36 (1990).

60759 Feyling-Hanssen, R., Funder, S. \& Strand Petersen, K. The Lodin Elv Formation, a Plio608 Pleistocene occurrence in Greenland. Bulletin of the Geological Society of Denmark 31, $609 \quad$ 81-106 (1982).

61060 Gradstein, F. \& S., B. Cainozoic bathymetry and palaeobathymetry, northern North Sea 611 and Haltenbanken. Norsk Geol Tidsskr 76, 3-32 (1996).

61261 King, C. in Stratigraphical Atlas of Fossil Foraminifera (eds D.G. Jenkins \& J.W. Murray) 613 (1989). 
61462 Hofmann, J. C., Knutz, P. C., Nielsen, T. \& Kuijpers, A. Seismic architecture and evolution 615 of the Disko Bay trough-mouth fan, central West Greenland margin. Quaternary Science 616 Reviews 147, 69-90, doi:10.1016/j.quascirev.2016.05.019 (2016).

61763 Perez, L. F., Nielsen, T., Knutz, P. C., Kuijpers, A. \& Damm, V. Large-scale evolution of the 618 central-east Greenland margin: New insights to the North Atlantic glaciation history. 619 Global and Planetary Change 163, 141-157 (2018).

62064 Laberg, J. S., Forwick, M., Husum, K. \& Nielsen, T. A re-evaluation of the Pleistocene 621 behavior of the Scoresby Sund sector of the Greenland Ice Sheet. Geology 41, 1231$6221234(2013)$.

62365 Nielsen, T. \& Kuijpers, A. Only 5 southern Greenland shelf edge glaciations since the $624 \quad$ early Pliocene. Sci Rep-Uk 3 (2013).

62566 Richter, C., Maxwell, S. B., Acton, G. \& Evans, H. F. in American Geophysical Union, Fall $626 \quad$ Meeting, abstract ID GP41E-03 (2013).

62767 Gradstein, F. M., Ogg, J. G., Schmitz, M. \& Ogg, G. The Geologic Time Scale. 1176 (Elsevier $628 \quad$ Science Ltd, 2012).

62968 Thiede, J., Jessen, C., Knutz, P., Kuijpers, A., Mikkelsen, N., Nørgaard-Pedersen, N. \& 630 Spielhagen, R. Millions of Years of Greenland Ice Sheet History Recorded in Ocean 631 Sediments. Polarforschung 80, 141-159, doi:hdl:10013/epic.38391.d001 (2011).

632

633 Data availability

634 All seismic data that support the findings are publically released and can be requested from 635 the GEUS data department (www.GEUS.dk)

636 637 
638 